Christos TEREZIS

Lydia PETRIDOU*

\title{
THE THEORY ON "EIDE" ACCORDING TO NICHOLAS OF METHONE
}

The relation between "eidos" ("form") - i.e. the including all of the sensible beings formative, decorative and deterministic ontological reality - and "matter" - which is considered to be the factor that receives a number of rational formations and constitutes the substrate of the specifications and individuations that the sensible world reveals - is a main issue in the themes covered by the ancient Greek Metaphysics and Cosmology. Since the foundation of the Platonic Academy and the Aristotelian Lyceum and until the last Neoplatonic philosophers and Aristotelian commentators the research questions - and the interpretative, often in an axiomatic way, approaches - that refer to the above pair and to the qualitative and quantitative specifications or formations that it causes, hold the attention not only of the philosophical but also of the theological researches. Actually, this is a topic that was connected with specific details of epistemological foundations, regarding both the structure of the metaphysical and physical world and the relations between them, in the sense mainly of a relation between an archetype and an image. These questions are also found in the theories of the Eastern Christianity, since the time of Clement of Alexandria and Origen, who somehow represent Platonism of Alexandria. In general, this presence is due to the fact that it is not reasonable for a society with a theocentric orientation - like the initially Hellenistic Christian, which was then developed into Byzantine - not to put in the center of its interest important questions concerning the relation between God, who is believed to be the supreme and only Principle, and the natural world and, more specifically, human being. From a strictly theoretical point of view, we see very often the Byzantines approaching and analyzing several issues that had concerned the ancient Greeks. Among them, the ontological ones are the most important, since they refer to the very cores of the divine reality construed as a cause and of the cosmos construed as an effect. The research interest permanently relies on how these issues

\footnotetext{
* Prof. dr Christos Terezis - Professor of Ancient Greek and Byzantine Philosophy at the Department of Philosophy in University of Patras in Greece; e-mail: terezis@upatras.gr; Dr Lydia Petridou - Independent Scholar of the Ancient Greek and Byzantine Philosophy in Greece; e-mail: petridoulydia@yahoo.gr.
} 
are formed over time and on what extend they gain modern or even radical approaches. Or, in other words, according to what criteria are any reconstructions made? It is obvious that history should be connected with systematicity, actually under conditions of interactivity.

1. Ancient Greek dualism and Christian monism. First of all, we have to point out that between the ancient Greek, until the $2^{\text {nd }} \mathrm{c}$. $\mathrm{AD}$, and the Christian thought crucial differences regarding the relation "eidos-matter" are found, which are due to the fact that each one of them provides a unique worldview about the production of the sensible world. More specifically, the ancient Greek thought, almost in all of its theories until the period of time that we are discussing, accepts - choosing clearly dualism and rejecting the ex nihilo creation of beings ${ }^{1}$ - the self-existent character of matter and a natural independence from its presence. More specifically, ancient Greek philosophers think of matter either as formed by the creative intervention of the metaphysical archetypal "eide" (Platonism) ${ }^{2}$ or as possessing a potentiality $(\hat{\varepsilon} v \delta v v \alpha \alpha \mu \varepsilon \imath)$ for self-formation in accordance with the originally inherent in it "eide" (Aristotelianism) 3 . Original, however, productive autonomy is actually not accepted for the matter, which is permanently determined as to its actions for formations by the programmatic interventions of the divine world, which are clearly characterized by decorative features. On the contrary, in the Christian teaching, since the beginning and actually intensively during the Byzantine period, the theory on the creation of the natural world receives

${ }^{1}$ Cf. for instance, Aristoteles, Metaphysica Z, 1032b, ed. G.P. Goold: Aristotle Metaphysics

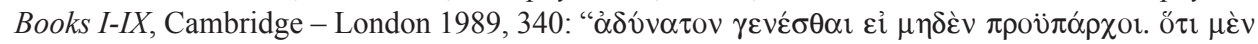

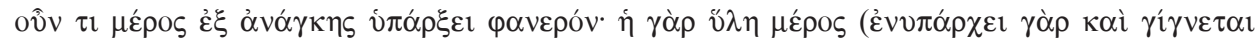

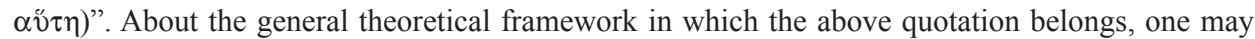
read B. Dumoulin, Analyse génétique de la Métaphysique d'Aristote, Paris 1986, 121-168. We could suggest that the hylozoic Pre-Socratic philosophers are an exception in the dualistic tendency of the ancient Greek philosophy. Furthermore, we should not exclude the Eleatic philosophers, who orient themselves towards the metaphysical monism and accept that the natural universe exists without any ontological value.

${ }^{2}$ Cf. for instance, Plato, Timaeus, 30a, 2-6, ed. G.P. Goold: Plato, Timaeus, Critias, Cleitophon, Menexenus, Epistles, Cambridge - London 1966, 54. About the content and the functions of the matter in the Platonic philosophy, one may read D.J. Schultz, Das Problem der Materie in Platons Timaios, Bonn 1966. T.G. Sinnige, Matter and Infinity in the Presocratic Schools and Plato, Assen 1968.

${ }^{3}$ Cf. for instance, cf. Aristoteles, Metaphysica H, 1024a-1045b, ed. Goold, p. 414-426. We have to mention that according to Aristotle matter becomes active so as to be self-formed by the interven-

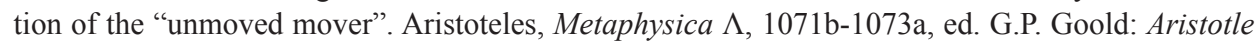
Metaphysics Books X-XIV, Cambridge - London 1990, 138-154. P. Aubenque, Le problème de l'être chez Aristote, Paris 1991, 431-438. Concerning the issue on universals in general, one may also read H.J. Krämer, Aristoteles und die akademische Eidoslehre: Zur Geschichte des Universalienproblems im Platonismus, "Archiv für Geschichte der Philosophie" 55 (1973) fasc. 2, 119-190; The Problem of Universals, ed. Ch. Landesman, New York - London 1971; M.J. Loux, Substance and Attribute, Indiana 1978, Das Universalienproblem, ed. W. Stegmüller, Darmstadt 1978. 
a different prospect; according to its representatives any view on dualism is excluded, while at the same time the ex nihilo creation of the beings is explicitly accepted ${ }^{4}$. For Christian thinkers, "matter" is considered as lacking of self-existence and is understood as a product of a rational texture resulting by Triune God's creative volition and energy. This is actually considered to be a complicated condition with a quantitatively infinite multiplicity and a lot of characteristics. These two ontological transcendent conditions take matter from non-existence, bring it into existence and give to it the forms in which it will manifest as a harmonious whole of coherent relations subject to strict regularities, as a created world that is subject to becoming under the terms of a continuously regulative organized construction. For instance, in Gregory of Nyssa we read the following:

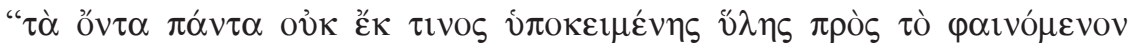

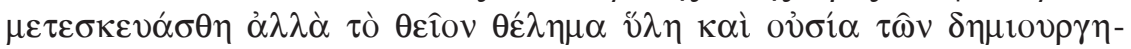

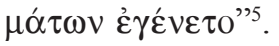

And

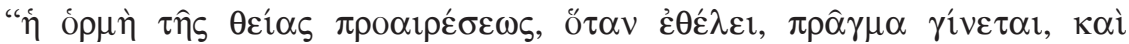

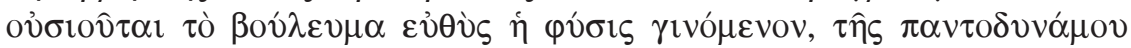

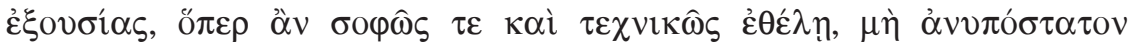

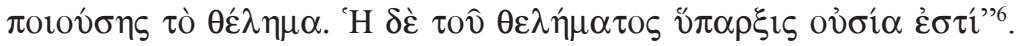

We have to mention that according to the Christian point of view about the creation, the "matter" and the forms in which it appears are not two different between each other ontological terms, but, through their special in each case combinations, co-constitute the essence of the beings. Basil of Caesarea (the Great) says:

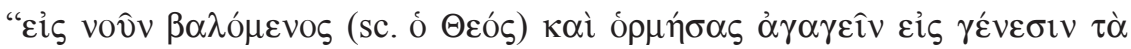

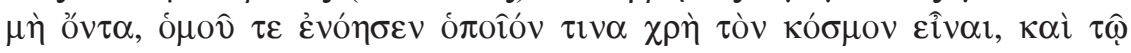

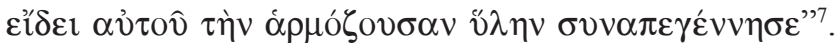

${ }^{4}$ Cf. V. Lossky, Essai sur la Théologie Mystique de l'Église d'Orient, Paris 1973, 87-108.

${ }^{5}$ Gregorius Nyssenus, In Illud: Tunc et ipse filius, PG 44, 1312A. Indicative studies for a general approach of the above are the following: S.W. Gustafson, Gregory of Nyssa's Reformulation of Christian Thought: Some Paradigmatic Implications of his Doctrine of Divine Infinity, Madison 1985; R.F. Harvanek, The Philosophy of Creation of St. Gregory of Nyssa, New York 1944; H.U. von Balthasar, Présence et pensée. Essai sur la philosophie religieuse de Grègoire de Nysse, Paris 1942, 1-80; J. Daniélou, L'être et le temps chez Grégoire de Nysse, Leiden 1975, 75-132; A.A. Mosshammer, Non-being end evil in Gregory of Nyssa, VigCh 44 (1990) 136-167.

${ }^{6}$ Gregorius Nyssenus, De anima et resurrectione dialogus, PG 46, 124B. The usage of the term ov $\sigma i \alpha$ refers to the content of the divine will and, on the one hand, to what it is able to accomplish through its manifestation and, on the other, to what is eventually constituted as a cosmic reality. So, we have to study the term ov $\sigma i \alpha$ under the principle of analogy. Then, a number of meanings come to the fore.

${ }^{7}$ Basilius Caesariensis, Homiliae in hexaemeron 2, 2, PG 29, 33A. Typical studies for a general 
The divine planning is confirmed even further without any external additions. We have to mention here that the idea of participation of the sensible beings into the intelligible ones is found in Plato and the Christian thinkers, as both a communication and a distinction between each other. Note, however, that their cosmotheoretical views are clearly different ${ }^{8}$.

2. The monistic reconstruction of the ancient Greek ontology. We should, however, mention that in the $3^{\text {rd }} \mathrm{c}$. AD and thenceforward the last current of thought of the Platonic Academy, i.e. Neoplatonism, adopts a consistent monism and, especially with Proclus $\left(5^{\text {th }} \mathrm{c}\right.$.), attributes to the divine creation volitional qualities ${ }^{9}$. So, from this point on we may refer to a common ontological example, despite the fact that Neoplatonism adopts polytheism and Christianity monotheism. Another common feature of the two worldviews is their teleological orientation. This direction provides the chance for their representatives to characterize the supreme Principle as Good, which, except from its other properties, is considered to be completely desirable, the entity that offers the suitable meaning to every form of existence and to which everything tends to return ${ }^{10}$. This is an ontological paradigm entirely optimistic.

3. Nicholas of Methone and the Christian readings on Ontology - General positions. The Bishop of Methone, Nicholas, was a Greek Scholar of the $12^{\text {th }}$ century. He took action mainly in Peloponnese, during the reign of Manuel I Komnenos approximately in $1155^{11}$. He was one of the most educated

approach of the above are the following: M. Orphanos, Creation and Salvation according to St. Basil

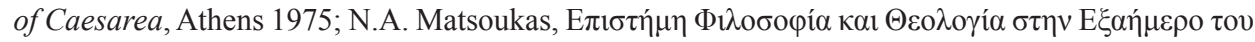

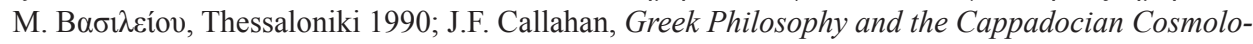
gy, DOP 12 (1958) 29-57.

${ }^{8}$ For instance, E. Gilson (L'esprit de la philosophie médiévale, Paris 1989, 98) says that "pourquoi toute métaphysique chrétienne requiert l'usage des notions de similitude et de participation, mais leur donne un sens beaucoup plus profond que le Platonisme auquel elle les emprunte, car la matière dont use le Démiurge du Timée n'est qu'informée par les idées auxquelles elle participe, au lieu que la matière du monde chriétien reçoit de Dieu son existence en même temps que l'existence de ses formes. Nous n'ignorons pas quelles difficultés on peut accumuler sur ce point, mais il n'en est peut-être pas une qui n'en soulève elle-même davantage. Que la notion de participation répugne à la pensée logique, c'est chose possible, puisque toute participation suppose que ce qui participle est et n'est pas ce dont il participle [...]. Sans la doctrine de l'analogie, l'identification de Dieu et de l'être donne naissance au panthéisme".

${ }^{9}$ Cf. Proclus, Theologia Platonica II-VI, ed. H.D. Saffrey - L.G. Westerink: Proclus, Théologie Platonicienne I-VI, Paris 1968-1997.

${ }^{10} \mathrm{Cf}$. ibidem I. For a general approach of the specific issues of this treatise, one may read the collective volume of ed. A.Ph. Segonds - C. Steel, Proclus et la Théologie Platonicienne, Leuven - Paris 2000. Do, however, note that, since the Neoplatonic Scholar adopts polytheism, he analogously ascribes the concept of good to all the individual gods. He actually thinks of it as their original ontological property, passed from deity to deity in a descending hierarchically manner.

${ }^{11}$ On this issue, cf. P. Magdalino, The empire of Manuel I Komnenos, Cambridge 1993, esp. 332. 
and brightest philosophers and theologians of his time, who wrote a number of treatises, in full knowledge of his scientific mission: the defense of the Christian doctrines. In his effort to provide a satisfactory answer to Platonism and Neoplatonism of his time and in order to express his opposition to the idealistic nominalism that was influencing the Christian theory too, he strongly defended Christian realism, especially in his treatise entitled 'Avó $\pi \tau v \xi ı \varsigma \tau \eta \varsigma$

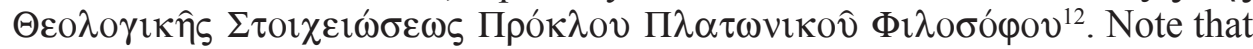
whether this study is an original work or just repeats already existent views is an issue to be investigated ${ }^{13}$. We could, however, support that Nicholas draws arguments from the previous attempts of refuting Proclus and that the text, as to the structure of thought and the style, is a typical example of his writing. We have to mention too that he is included in Areopagite's tradition, which he utilized according to the new philosophical data that meanwhile had arisen.

The essence and the formation of the "matter", as well as the content and the function of the "eide", are main issues in Nicholas of Methone's treatises. Although in general he does not systematically speak about ontological and cosmological issues, in his analyses the basic principles of Christianity about the creation of the natural universe as the expression of the divine Revelation (active causality), as a theophany, are found with strict consistency. So, in

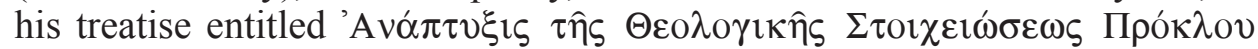

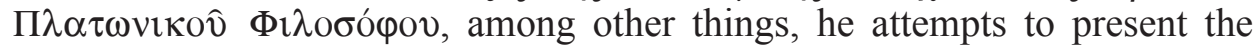
Christian aspect on the relation between "eide" and "matter", while at the same time he refutes the views expressed on the topic by Proclus ${ }^{14}$, which mainly rely on polytheism - multi-causality and on the multi-dimensional and hierarchically structured determination of these two co-operating ontological factors for the creation ${ }^{15}$. For instance, the "eide" receive their characteristics from all of the gods who develop into the metaphysical universe.

First of all, it is necessary to mention that Nicholas, having thoroughly understood the spirit of (Pseudo) Dionysius the Areopagite's writings and the following tradition - with Maximus the Confessor being its main representative,

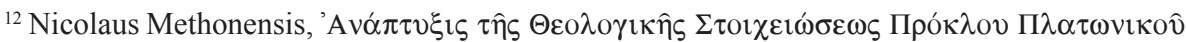
$\Phi ı \lambda$ oбópov, ed. A.D. Angelou: Nicholas of Methone, Refutation of Proclus' Elements of Theology, Athens - Leiden 1984.

${ }^{13}$ On this matter, one may read M. Trizio, Eleventh - to twelfth - century Byzantium, in: Interpretating Proclus: From Antiquity to the Renaissance, ed. S. Gersh, Cambridge 2014, 198-226.

${ }^{14}$ We have to mention that Nicholas' criticism is mostly related to the treatise entitled Institutio theologica, or, at least, he doesn't seem to be interested in the Neoplatonic philosopher's other treatises. On this issues, G. Podskasly, Nikolaos von Methone und die Proklosrenaissance in Byzanz, OCP 42 (1976) 509-523.

${ }^{15}$ Proclus analyzes his polytheistic system to all of his treatises. The most systematic, however, analysis is presented in his six-volume treatise entitled Theologia Platonica, ed. ibidem, in which he attempts to summarize the entire development of the ancient Greek Metaphysics. His basis is Plato's dialogues, the similarities of which, regarding the metaphysics of transcendence and the metaphysics of immanence, i.e. the source of cosmology, Proclus attempts to show. 
- presents his views remaining clearly within the ontological metaphysical and physical realism of the Eastern Christianity. By this, we mean that he adopts the idea that the "universals" - "eide", "ideas", "logoi", "paradigms" - possess an a priori and real existence outside and independently of the human thought. More specifically, according to Eastern Fathers' theology - which does not exclude the a posteriori intellectual comprehension or verbal expression - "universals" appear in two levels, the transcendental and the intra-world. Originally, they exist within triune God independently of their sensible manifestations, as pure metaphysical realities; then, they function as the intelligible plan of the produced world, without any external interventions or necessities. In purely Christian terms, they are the projection of God's uncreated powers, energies, "processions", the specific manifestations of the divine will, according to combinations-plans that determine what is going to be done. Then, the planning is manifested and in this way through their logical and productive activation, they become the ontological substratum for the emergence and the formation of the sensible world, i.e. of the material beings that are going to receive form, actually one of a kind for each one of them at least regarding the general category to which it belongs ${ }^{16}$. Note that the above considerations are not subject to the human perception, but axiomatically derive from the adopted by Christians ontological monism and absolute divine goodness.

4. The "eide" as the content of the divine Mind. According to Nicholas, "eide" of beings are divine thoughts. That being said, it becomes clear that the Christian thinker is a part of a long tradition, the representatives of which were of the opinion that the "eide" are God's concepts-thoughts, the logical shapes-plans, which the supreme Principle, God, forms into his thought and by which he produces the created world. In other words, these are the residing into the divine Mind realities-ontological constructional schemes. This view is a given in Christian thought, but its historical-philosophical source is found in ancient Greek ontology and, actually, during its post-classical period of time ${ }^{17}$. The view that the "eide" are God's innate intelligible plan for the production of the sensible world, i.e. the content of the divine Mind, was actually established in the $1^{\text {st }} \mathrm{c}$. BC (Poseidonius, Philo, Seneca and others) ${ }^{18}$. This is a position that

\footnotetext{
${ }^{16} \mathrm{Cf}$. for instance, Pseudo-Dionysius Areopagita, De divinis nominibus 5, 8, PG 3, 824C; Maximus Confessor, Quaestiones ad Thalassium, PG 90, 239D - 296A; idem, Ambiguorum liber, PG 91, 1080A.

${ }^{17}$ This question initially appears in Antiochus of Ascalon and Atticus, who represent Platonic eclecticism. The critical edition of Atticus' Fragments (ed. des Places, Paris 1977), offers reliable information on the topic and on the reasons why it emerged. Regarding the historical development of the issue until Neoplatonic Proclus, one may read Al. Kojéve, Essai d'une histoire raisonée de la philosophie païenne, vol. 1-3, Paris 1973.

${ }^{18}$ The first attempts for overcoming dualism and for adopting monism start to appear with the representatives of the Middle Platonism. For instance, one may read N.M. Rich, The Platonic Ideas as the Thoughts of God, "Mnemosyne" 7 (1954) 123-133.
} 
results from a peculiar, but actually useful, for the development of the theory on "universals", synthesis - and not just presentation - of the Platonic (on the transcendence of the archetypical "eide" over the sensible beings) with the Aristotelian views (the "eide" are the innate formative properties in matter). I.e. we are not speaking about two kinds of "eide", but just one, which is structured successively in two non-contradictory levels. In this case too, "eide" are originally placed into the metaphysical universe and, then, they constitute the natural world, without actually their intervention to affect their ontological integrity at all. I.e. they are identified by a hyper-plenitude, which ensures them the ability to manifest themselves continually and in various ways; this is a necessary condition for the continuation and the development of the physical world.

At this point, however, we have to emphasize that the aspect on the absolutely innate character of the "eide" under the light of their own presence into the divine "being" is not accepted by the Christian thinkers, since it easily leads to the view that these intelligible plans - as well as their productive possibilities - originally inhere in God. I.e. they are his original essential properties. For Christians, an accepted idea is that the "eide" exist into God, in the sense that they develop in his mind as let's say products of his volition, as it will become clearer bellow, in the sense that he somehow activates timelessly specific procedures of, so to speak, self-reference. The "eide", as specific models of the creation, are not from the beginning self-powered and perpetual together with God's essence or mind conditions, since in this case the created world in the form of its intelligible archetypes would be inherent in God. The result then would be to accept almost without any hesitation that God productively effuses through his ontological constitution, i.e. forced by a necessity his innate concepts-plans would cause - his own hypostasis, - and not by his volition. Undoubtedly, such an idea would change Christian God's personal character and would exclude from the outset his loving appearance-relation to the beings, since he would initially possess them in his ontological field as eternal possibilities. During the entire development of the Christian theology, the personal relation, as originally emerging from God's own choice, is not determined by a condition that would be set by himself as a necessity, but is exclusively determined by a free expression of will, which does not depend either on the limits of the essence or the abilities of the mind; and by this we do not mean that he is not connected to them; quite the opposite, he is connected to them and, actually, in an inseparable way. Ontology obviously is not discarded, but constitutes the crucial issue and the basis of what is going to be developed. It would be, however, unreasonable not to say that both the divine essence and the divine mind are absolutely free. Christians' triune God brings to existence a reality completely new and not one that he owned in a self-founding way and in a certain moment would turn it into sensible world, regardless of his will and acting in the sense of a mechanistic ontological 
development or an emanating automatism to which he would actually surren$\mathrm{der}^{19}$. Furthermore, we would ask ourselves why the product occurs as sensible and not exclusively as intellectual, as the angels are.

It also becomes clear why we would be far from the truth, if we were under the impression that the divine mind and the divine energy are not inherent in the divine essence realities. An idea about a God being in the first level of his existence without thought and active "readiness" would be completely unfamiliar to Christian views on the self-founding absoluteness ${ }^{20}$. These conditions exist since ever together with the essence and are manifested a posteriori - without the insertion of time or the transition of space - in a specific content and through such plans that pre-show the created world; they are caused by the divine will, which is also inherent in the divine essence ${ }^{21}$. Without any doubt, the essence as their precondition possesses ontological priority over energy, thought and volition, but certainly it is not possible to assume that it initially lacks of these conditions and that they occur later as its accidents. Priority, however, does not mean also an ontological hierarchy; otherwise we would be speaking about polytheism, inferior polyarchy and submissive relations.

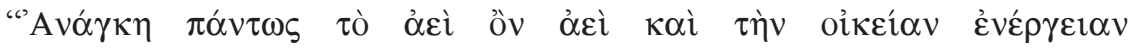

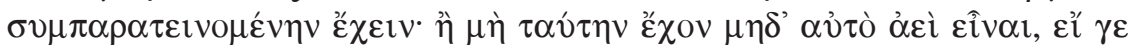

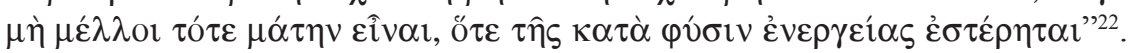

If the essence was lacking of these conditions, it would be forced by its poverty to receive them from outside; this would be a reception that at the same time would lead the essence to fall into the condition of the synthesis and to the mandatory-permanent determination by its components. Then, the divine essence would be imperfect and it would fail to resist certain processes, in order to acquire its hypostatic completeness. Such extensions-questions are endless.

By thinking Nicholas the "eide" as being God's intelligible content - and certainly not as being his ontologically natural content, since they are not core texture substances but concepts, - he comes to the conclusion that they exist within God before their perceptible appearance, which obviously is specified in many ways.

\footnotetext{
${ }^{19}$ Cf. Basilius Caesariensis, Homiliae in hexaemeron 1-9, PG 29, 4-208.

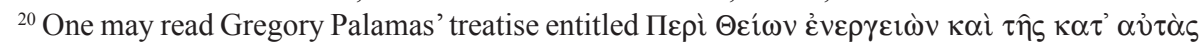

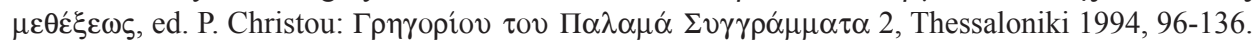
This is a treatise that includes into strict epistemological limits and precise conceptual categorizations the entire tradition of the Eastern Christianity, having as its foundation Areopagite's writings.

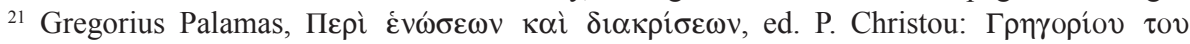

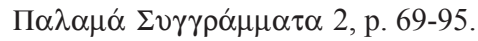

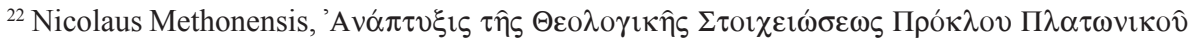
$\Phi ı \lambda$ oбó $\varphi$ ov 56, 2-4; the first digit indicates the page of the edition of Angelou, and the next particular lines. Cf. Maximus Confessor, Ad Sanctissimum Presbyterum Marinum, PG 91, 200B.
} 


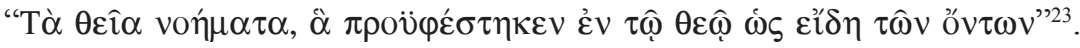

I.e. they have an a priori nature (ante res) and their existence is not only absolutely independent from the sensible things but also from their own creation. I.e. they do not acquire their existence into the natural produced beings. Thus, it is not right to think of them as an obligatory enhypostatic reality; furthermore, they cannot initially be defined as conceptual "universals". Without doubt, the Christian thinker explicitly accepts the transcendental realism and its priority over the intra-world realism (the "eide" in rebus). At the same time, the "eide" are for the sensible beings non-material - and, consequently, ontologically superior to them - realities ${ }^{24}$, while they are the proof, according to this absolutely rational nature of them, that God knows and pre-defines beings before leading them from nonexistence to existence:

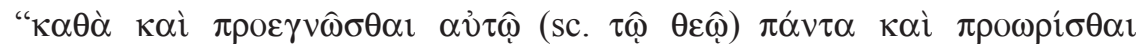
$\lambda \varepsilon \dot{\gamma \varepsilon \tau \alpha \imath " 25 .}$

At this point, an epistemological detail, with actually great ontological foundations, appears. Specifically, God gets to know first himself; i.e. we are speaking about an internal cognitive motion, without this meaning that he actually doubles himself. Since he is absolute, God does not get knowledge a posteriori or by realities that are found into the sensible world. If that was the case, God would fall under certain processes, in which he would have to proceed in order to fulfill a - at least temporary - deficiency of his. I.e. "eide" constitute the pre-considered - a priori - and metaphysical planning of the sensible world, which is not either random or mechanistic; this is a view found also in Areopagite's writings and is a common place of the Christian tradition ${ }^{26}$. We are speaking about the specialized projection of the divine Revelation-providence, i.e. this is a way that shows the absolute rationality. We have to mention that this rationality in not fully assimilated by the physical universe, at least for as long as it is subject in the process of becoming. A complete assimilation would mean the realization of teleology.

5. The volitional character of the "eide". Furthermore, Nicholas, following here too with great consistency pseudo-Dionysius and the entire patristic tradition, thinks that the "eide", which inhere in God, are his good volitions.

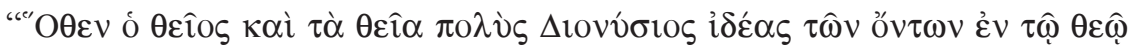

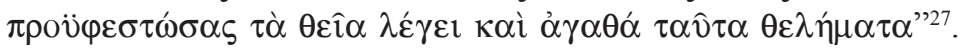

${ }^{23}$ Ibidem 154, 15.

${ }^{24}$ Cf. ibidem 154, 16.

${ }^{25}$ Ibidem 154, 16-17.

${ }^{26}$ Georgius Pachymeres, Paraphrasis "De divinis nominibus" Dionysii Areopagitae 5, 8, PG 3, 844C - 848D.

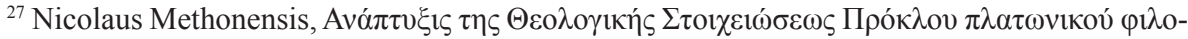
бópov 79, 10-12. In the general context, it is explained that volitions are not a supervening condi- 
Once again, we realize that "eide" are not the ontological content of God's essence, i.e. they are not realities originally inherent as equivalent in his essence. The term $\alpha$ ' $\gamma \alpha \theta$ óv shows their great property-attribute, which was bestowed to them, and not their self-founding condition. It defines the teleological orientation that they activate. They are not considered as a different substance of the same, but classified, with One's essence ontological quality - such a view would undoubtedly lead to the rejected by Christian thinking pantheism, - but they express his volitional externalizations, in order a new reality to emerge. The possibility for multiple substances in the transcendental area of the divine being is explicitly excluded. Nicholas says that God " $\alpha \nu \tau \hat{\varphi}$

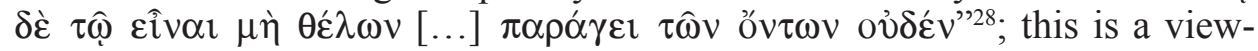
point which means that the creation, as defined by the divine intention, is not ontologically related to the divine essence and is not an incomplete image or an inferior repetition of it. A production only by the divine emanation is not accepted by this cosmological example. It would form an absolute type of monism without any exceptions, which would prioritize into the same ontological field the causes and the effects (pyramidical development). From the gnoseological point of view, the principle of analogy would be defined as similarity among beings that are ontologically of the same nature, although not equivalent regarding the possession of the common ontological status. Equivocation would then be completely independent from any otherness and would just show distinctions, a limitless pantheism with hierarchy as to the completeness of the same essential content.

6. The "eide" in view of unions and distinctions. Apart from their above properties, "eide" develop into the divine area as a unified but internally differentiated whole. Specifically, among them there is an unbreakable unitycommunication and, at the same time, each one of them distinguishes itself from the others by both the specific content of its property - but not of its essence, - and the pure condition of its archetypical individuality. By repeating Proclus $^{29}$ and Areopagite's ${ }^{30}$ similar views, Nicholas points out that:

tion in God, but exist initially in a hyper-founded way together with the rest of the conditions of the divine existence. Note also that they are not examined as emotional or psychological conditions, which, as variously formed, belong only to human beings. By this, anthropological terms are not transferred into theology.

${ }^{28}$ Ibidem 79, 12-13.

${ }^{29}$ Cf. Proclus, In Platonis Parmenidem 757, 4-11, ed. D.R. Morrow - J.M. Dillon: Proclus' Commentary on Plato's Parmenides, New Jersey - Oxford 1987, 126. See W. Beierwaltes, Proklos. Grundzüge seiner Metaphysik, Frankfurt am Main 1979, 32-34.

${ }^{30}$ Cf. Pseudo-Dionysius Areopagita, De divinis nominibus, 2, 4, PG 3, 640D - 641A; 2, 5, PG 3, 641D - 644A; 2, 7, PG 3, 644D - 645A. Also, E. Corsini, Il trattato "De divinis nominibus" dello Pseudo-Dionigi e i commenti neoplatonici al Parmenide, Torino 1962, 39-42. 


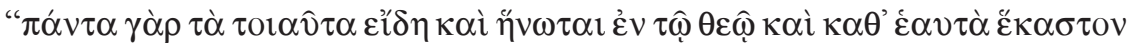

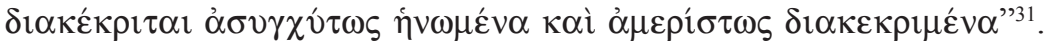

In order to understand his point for this dual presence of the "eide", it is necessary to rely on the Christian teaching about monotheism and, by extension, about the production in view of the active one-causality, which is activated in many ways. More specifically, the "eide", on the one side, should be in an absolute unity, since they are God's intellectual conceptions and not individual productive divine entities with self-existence and with their own special substance and energy. Unity arises from the fact that it is not possible ontological separations to exist into God; this is a reasoning that may be applied also vice versa. On the other side, each one of these "eide" is of a particular content, since it is a metaphysical model of a world that will be formulated with specific qualitative and quantitative ontological appearances or with clearly defined to each other ontic genera. Therefore, the distinction of the "eide" is the metaphysical and archetypical model of the separations found into the creation, obviously regarding their generality. This is, however, a prefiguration, which is perceived by human mind because of a rational necessity, on the basis of the principle of analogy. Gregory of Nyssa had brought to the light also the ability of the matter or of the natural world to function under conditions of internal differentiation and to cause continually quantitatively infinite productive varieties ${ }^{32}$. This is a detail of major cosmological importance, since it excludes the possibility of a passive matter, which mechanistically would repeat what it had received. I.e. it is considered that matter takes initiatives, provided that it utilizes the coexisting in it "eide" and that until the time that it fully actualizes them is incomplete ${ }^{33}$.

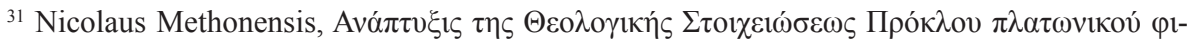
$\lambda$ oбópov 154, 17-19. The union and the distinction define a dialectic that has been formed into the divine area by its self-founding condition. Since it is a posteriori and as divine ad extra "procession", we could find the creative projections of the divine energies and the Incarnation of the divine Logos in the person of Jesus Christ.

${ }^{32}$ Cf. Gregorius Nyssenus, Contra Eunomium III 20, 11-22. We could here speak about Gregory Palamas' Aristotelianism, since crucial possibilities-initiatives are given to the matter. In general, about Aristotelianism in Byzantium and with quite frequent references to Nicholas of Methone one may read G. Podskalsky, Theologie und Philosophie in Byzanz, München 1977, 64-87 and 107-124. Also, K. Oehler, Aristotels in Byzanz, in: Antike Philosophie und byzantinisches Mitelalter: Aufsätze zur Geschichte des friechischen Denkens, München 1969, 272-286. Important personalities like John the Philosopher, Eustratius of Nicaea and George Pachymeres capture a particularly profound Byzantine reading of Aristotle.

${ }^{33}$ This is, however, a matter that raises many questions, which Nicholas in some parts of his study has highlighted. Quite indicatively, we note that in paragraph 75, 7-16 he repeats using indirect speech a comment of Basil the Great (Bishop of Caesarea) on the biblical Genesis. He says that the Cappadocian thinker emphasizes that God did not create at first a matter without "eidos", i.e. without any possibility of existence. He created sky and earth, i.e. the upper and the lower bodies respectively, with their necessary quantities and qualities. Furthermore, these bodies did not left 
7. In the direction of a Christian Hylomorphism. For Nicholas, therefore, the created world is the sensibly actualized planning of God's energies, through their rational and structural projections. The sensible beings are the bodies, in which there is no separation between their "matter" and their forms in which they appear. As we saw in the previous reference, the Christian theologian, thinking of the relation between the material substrate of the beings and their formed manifestations, decisively points out that, apart from a purely theoretical level, it is not possible for human beings to perceive "matter" without "eide". The separated from "matter" "eidos" exists only as captured by a conceptual thinking, in the processes of which distinction and analysis are accepted for clearly methodological purposes, regarding the intended theoretical result. From this conclusion it becomes clear that human research makes some technical "maneuvers" to make easier the research processes ${ }^{34}$. Therefore, only through cognitive processes "eidos" and "matter" are separately conceivable. Pragmatologically speaking, such an idea is in general epistemologically risky, since it would lead to an extreme reversal of the Christian worldview and, by extension, of the theory about the - actually not simplistic - monistic way of God's creative expression.

More specifically, it is not possible to consider "matter" independently from the forms in which it sensibly appears, since then we would have to accept that God created initially "matter" deprived of its qualitative and quantitative formations and, consequently, in a condition not capable to actualize any (self-)formative motion. If God realized such a condition, he would then be pushed to interfere with "eide", in order to correct a not successful initial productive externalization of his. Such a corrective addition would lead a researcher to skepticism about the integrity of the divine creative-provident ability. The acceptance of this dual intervention would actually cause an a posteriori dualism into the creation. At the same time, this dualism would lead - if this would not be presupposed - to the acceptance of an extreme ontological and evaluative superiority of the "eide" over the "matter", since it would be considered chaotic, undefined and deprived of the elements that would make it a rational creature. Meanwhile, we would have to accept that "eide" are accidents, a posteriori powers and formative realities of "matter", which are adapted to what it defines or is deprived of. So, "matter" would force necessities, which the "eide" would not be able to exceed. However, this view is completely incompatible with the Christian theory about creation. For the representatives of Christianity of both the East and the West, the effects from

without communication but they were connected through the mediation of the elements, which we could describe as matter. Within these elements the conditions for the creation in the future of all the other bodies were formed. Thus, Nicholas accepts a dynamic consideration of matter. We have to mention that Nicholas positions on matter and cosmic elements remain to the desiderata of research.

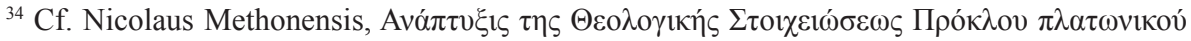

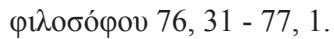


God's productive energies are formed; they are specific substances, regardless of whether they initially appear as such ${ }^{35}$. Either way, the developmental example is all over their teaching. As a further use of the divine bestowments, the result is a sequential presence of the natural phenomena as a cosmic enrichment or renewal ${ }^{36}$.

Accepting the above reasoning, Nicholas points out that each sensible being is a body not separated into two different - and a posteriori connected - realities, but exists from the beginning as a hypostatic unity and wholeness, at least in the sense of a developing seed. God did not create "matter" without quantity, quality and "eide". By giving a broader description of what we read in the paragraph mentioned in note 29 , he points out that:

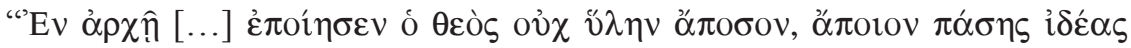

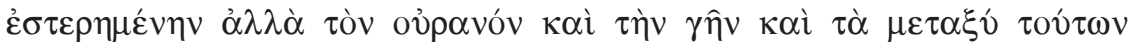

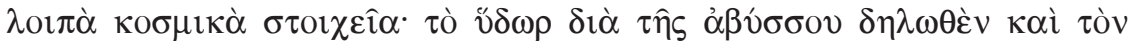

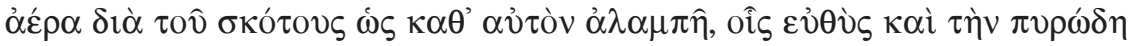

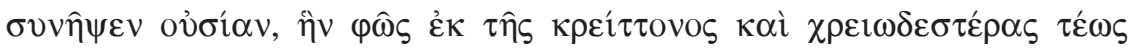

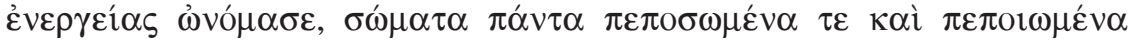
$\kappa \alpha \theta^{\prime} \varepsilon \alpha \nu \tau \alpha^{\prime \prime}{ }^{\prime 3}$.

Basil the Great has already pointed out this theory about the internally multiplicative quantitative and qualitative appearance and about the non-deprived character of the "matter" 38 ; similar views are also found in Gregory of Nyssa.

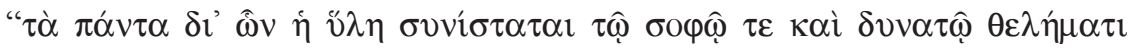

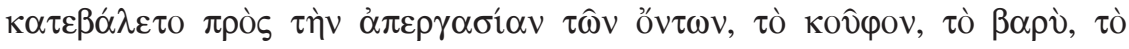

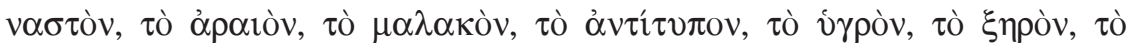

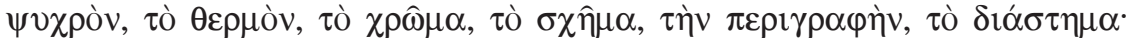

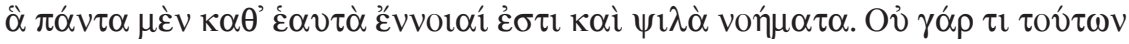

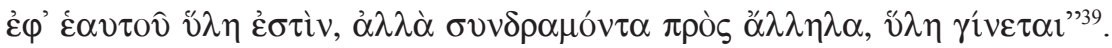

This is not just a combination of qualities and properties, but a universal mutuality, which obviously belongs to the above planning, which also defines the extensional presence that the natural phenomena will have. The matter becomes substance through the combinations of its natural properties, on which

${ }^{35}$ Cf. Gilson, L'esprit de la philosophie médiévale, p. 39-84.

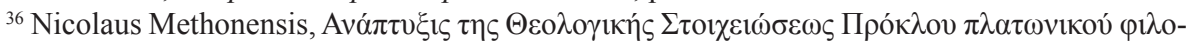
бópov 62,18-21 and 93, 16-18. This is a Christian reading of the Pre-Socratic approach on natural elements, especially of Empedocles.

${ }^{37}$ Ibidem 77, 1-7. In this excerpt we find out some interesting specifications on cosmic processes-changes made by the possessing quantities and qualities created bodies.

${ }^{38}$ Cf. Basilius Caesariensis, Homiliae in Hexaemeron I 1-11, PG 29, 3-28.

${ }^{39}$ Gregorius Nyssenus, Apologia in Hexaemeron 7, PG 44, 69C. It is interesting that every natural reason that comes from God is not actually material, so together with the rest possess priority over the matter. Do note that in this passage the priority does not devalue what falls into the becoming; quite the opposite. 
it absolutely depends. So, once again its non-self-sufficiency is proved, without, however, its initiatives being rejected. The term $\delta i \alpha ́ \sigma \tau \eta \mu \alpha$ is clearly connected to the development in space, a point that is expressed in a general way, since the boundaries of the natural universe depend exclusively on the divine planning. This is a topic that causes questions even in the modern era and is researched through assumptions.

Without doubt, by putting forward the a priori and transcendental character of "eide", Nicholas is not far from Platonism. On the other hand, by accepting that it is not possible to think the "matter" separately from the "eide", with the exception of a logical deduction, he moves in the direction of the Aristotelian view too. So, we may easily suppose that, starting from the Christian views about creation, he achieves a well-founded combination - and not just a reference or a collection - of the related views of the Academy and Lyceum. And this is a combination that is also interesting for the history of philosophy, since here what is left from perhaps the most famous - and undoubtedly very exciting - theory of the Greek thought is presented, which caused, at least at first, a number of controversies between these two emblematic Schools. Since "eide" are God's thoughts, they could not be deprived of the a priori and transcendental character in relation to their sensible manifestations. At the same time however, by not intervening in order to make sensible a self-existent and pre-existent of its formation "matter" and by constituting from the beginning bodies composed both of matter and form, they become the exact structural criteria of the phenomena, which support the infinite ways in which the sensible world is structured-developed. And it should be noted that the special way in which they are combined is considered to be above the possibilities of the human cognitive understanding.

According to what we have discussed, we believe that we are able to conclude that for Nicholas "eide" appear in two ways, as pure and as creative ontological schemes of a prolonged intervention. Originally, they are God's expression of the volition and thought and, then, they become sensible, not in themselves but by producing the created beings-bodies. The Christian thinker through his views about "eide" brings to the fore how the famous Christian theory on Triune God's "energies", during their productive presence, gets also philosophical content or we may interpret it also in a philosophical way. It should be noted that initially "energies" are God himself as an active and manifesting substance and, then, through the "eide" are the intermediate productive-archetypical realities through which the divine will becomes sensible world. And the fact that the "eide", even in some cases indirectly, are not the same with the energies, but they are the products - that belong to the core - of the combination of the divine energies, should be pointed out, since we have to 
avoid any suspicion of pantheism or extended emanation of God. In this way, Nicholas, being absolutely consistent to the realistic view of Eastern Christianity about creation, does not only bring up a reading of the philosophical past but also makes a really good combination of it. After all, he is an excellent example of a thinker who brings out the differences between Neoplatonism and Christianity. We may also include to his intentions the attempt to confirm the transcendence - and, by extension, the Godlike form - of the "eide" and to make argumentatively possible the exclusion of an intra-world dualism, which could not reliably explain the monistic way in which the transcendental element appears in sensible beings or, in other words, the way in which the divine will is being-produced. "Eide" represent the metaphysical multitude, which establishes and explains the natural one. The first is actually not known by human and hypothetically may be included into limited conceptual schemes.

Further discussion. Furthermore, we may say that Nicholas is totally opposed to any idea of Exemplarismus. By not accepting the self-existent character of "eide", he absolutely denies that God needs paradigmatic archetypes independent from himself, in order to create the world. Such a complementary reductionism or recourse is absolutely absent. As we saw, in his writings, "eide" are initially presented as the internal and with specific features separation of the divine will, thought and energy and, then, they function as the ontological basis for the establishment and the appearance of the multitude of the natural beings. Furthermore, the fact that he suggests about the creation a without parts and without separations hylomorphism, sets unity to be the most important category. And regardless of whether in a purely theoretical processing of the terms he believes that "matter" is a causa materialis and "eidos" is a causa formalis, he does not identify anyone of them with the substance of the beings. The created substance is from its first appearance the $\dot{\varepsilon} \xi \dot{\alpha} \mu \varphi 0 \hat{\imath} v$ composed, i.e. a universal functioning unity that is always specialized by the individual ones. This often found in his treatise point of view clearly shows his intention not to give any priority to nominalism, which he mainly uses it when he speaks about the cosmological issues on the time.

Finally, we have to mention that some decades later George Pachymeres (1242 - c. 1310), who is considered to be the most analytical and systematic commentator of Dionysius the Areopagite's writings and the most emblematic case of a Byzantine thinker who highlighted both the differences and the similarities between the two currents of thought, Neoplatonism and Christianity, worked on almost the same subjects. This tradition came to an end in the $14^{\text {th }}$ century by Gregory Palamas, who composed treatises with strictly special content, such as on energies, on unions-distinctions and on participation. We would say that by these treatises the Areopagetic tradition reaches its completion, since the dispersed in the texts of its representatives until that time concepts are included through advanced theories into a systematic area. Actually, the most important contribution of the Hesychast theologian is found in 
the presence-usage of the participation as a way of meeting - downwards and upwards respectively - of the intelligible with the sensible beings. The divine essence is explicitly excluded by such a process.

\section{(Summary)}

In this study, we are discussing the theory on "eide" and their relation to the "matter" according to Nicholas of Methone. This is a topic that shows the way in which God, as the supreme and only Principle, is connected to the natural world and human being. In this attempt of ours we move both historically and systematically. Thus, we first point out the differences on this issue between the ancient Greek thought, which moves towards dualism, and Christianity, which accepts only monism; we then explain the monistic reconstruction of the ancient Greek ontology by the Neoplatonists. Nicholas of Methone's views and the Christian readings of ontology constitute the core of our approaches, of which it is highlighted that "eide" are the content of the divine Mind and that they are the good divine volitions. The question is also put in view of the unions and distinctions, since "eide" are a unified but internally differentiated whole in God. At the level of the sensible world, it is shown that "matter" is not considered independently from "eide". The main conclusion that comes to the fore is that Nicholas of Methone makes a philosophical reading of the Christian theory on triune God's energies, remaining consistent with Christian realism and rejecting the self-existent character of the "eide".

\section{TEORIE NA TEMAT „EIDE” WEDŁUG MIKOŁAJA Z METHONY}

\section{(Streszczenie)}

Niniejsze studium omawia teorie „eide” i ich związek z „materią” według Mikołaja z Methony. Jest to zagadnienie ukazujące sposób komunikacji Boga, jako najwyższej i jedynej zasady, ze światem naturalnym i człowiekiem. Autorzy rozważają to zagadnienie zarówno na płaszczyźnie historycznej, jak i systematycznej. Najpierw wyodrębniają różnice w tej kwestii między starożytną myślą grecka, która skłaniała się ku dualizmowi, a chrześcijaństwem, które uznawało jedynie monizm; następnie wyjaśniają monistyczną rekonstrukcję starożytnej ontologii greckiej według neoplatoników. Stanowisko Mikołaja z Methony i chrześcijańska wizja ontologii stanowią centrum ich badań, w których podkreśla się, że „eide” są istotą Boskiego Umysłu oraz prawdziwymi Boskimi zamiarami. Kwestia dotyczy także związków i rozróżnień, ponieważ „eide” są jednolita, ale wewnętrznie zróżnicowaną całością w Bogu. Na poziomie zmysłowego świata wykazano, że „materia” nie jest rozpatrywana niezależnie od „eide”. Główna konkluzja studium jest taka, że Mikołaj z Methony dokonał filozoficznej interpretacji 
chrześcijańskiej teorii dotyczącej mocy Trójjedynego Boga, pozostając w zgodzie z chrześcijańskim realizmem i odrzucając samoistny charakter ,eide”.

Key words: Nicholas of Methone, eide, matter, monism, hylomorphism, divine energies.

Słowa kluczowe: Mikołaj z Methony, eide, materia, monizm, hylemorfizm, boskie energie.

\section{BIBLIOGRAPHY}

\section{Sources}

Aristoteles, Metaphysica, ed. G.P. Goold: Aristotle Metaphysics Books I-IX. Cambridge

- London 1989, Aristotle Metaphysics Books X-XIV, Cambridge - London 1990.

Basilius CAesariensis, Homiliae in Hexaemeron, PG 29, 4-208.

Gregorius Nyssenus, Apologia in Hexaemeron, PG 44, 61-124.

Gregorius Nyssenus, Contra Eunomium III, ed. W. Jaeger, GNO 2, Leiden 2002.

Gregorius Nyssenus, De anima et resurrectione dialogus, PG 46, 11-160.

Gregorius Nyssenus, In Illud: Tunc et ipse filius, PG 44, 1304-1325.

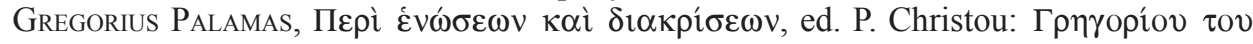

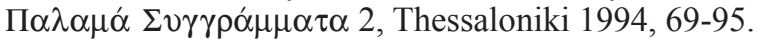

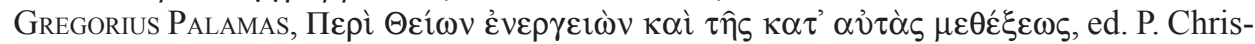

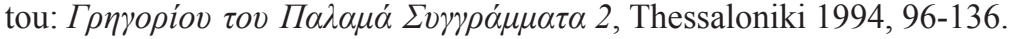

Maximus Confessor, Ad Sanctissimum Presbyterum Marinum, PG 91, 9-285.

Maximus Confessor, Ambiguorum liber, PG 91, 1032-1417.

Maximus Confessor, Quaestiones ad Thalassium, PG 90, 244-785.

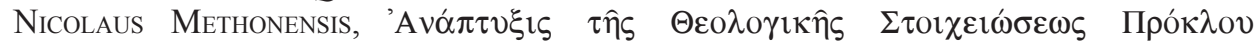

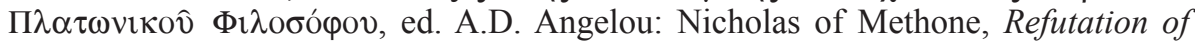
Proclus'Elements of Theology, Athens - Leiden 1984.

Plato, Timaeus, ed. G.P. Goold: Plato, Timaeus, Critias, Cleitophon, Menexenus, Epistles, Cambridge - London 1966.

Proclus, In Platonis Parmenidem, ed. D.R. Morrow - J.M. Dillon: Proclus ' Commentary on Plato's Parmenides, New Jersey - Oxford 1987.

Proclus, Theologia Platonica II-VI, ed. H.D. Saffrey - L.G. Westerink: Proclus, Théologie Platonicienne I-VI, Paris 1968-1997.

Pseudo-Dionysius Areopagita, De divinis nominibus, PG 3, 585-984.

\section{Literature}

Aubenque P., Le problème de l'être chez Aristote, Paris 1991.

Balthasar H.U. von, Présence et pensée. Essai sur la philosophie religieuse de Grègoire de Nysse, Paris 1942.

Beierwaltes W., Proklos. Grundzüge seiner Metaphysik, Frankfurt am Main 1979.

Callahan J.F., Greek Philosophy and the Cappadocian Cosmology, DOP 12 (1958) 29-57.

Corsini E., Il trattato "De divinis nominibus" dello Pseudo-Dionigi e i commenti neoplatonici al Parmenide, Torino 1962.

DaniéLou J., L'être et le temps chez Grégoire de Nysse, Leiden 1975.

Das Universalienproblem, ed. W. Stegmüller, Darmstadt 1978.

Dumoulin B., Analyse génétique de la "Métaphysique” d'Aristote, Paris 1986. 
Gilson E., L'esprit de la philosophie médiévale, Paris 1989.

Gustafson S.W., Gregory of Nyssa's Reformulation of Christian Thought: Some Paradigmatic Implications of his Doctrine of Divine Infinity, Madison 1985.

Harvanek R.F., The Philosophy of Creation of St. Gregory of Nyssa, New York 1944.

KoJÉve A., Essai d'une histoire raisonée de la philosophie païenne, vol. 1-3, Paris 1973.

KrÄMER H.J., Aristoteles und die akademische Eidoslehre: Zur Geschichte des Universalienproblems im Platonismus, "Archiv für Geschichte der Philosophie" 55 (1973) fasc. 2, 119-190.

Lossky V., Essai sur la Théologie Mystique de l'Église d'Orient, Paris 1973.

Loux M.J., Substance and Attribute, Indiana 1978.

Magdalino P., The empire of Manuel I Komnenos, Cambridge 1993.

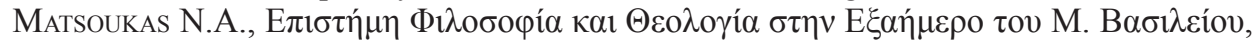
Thessaloniki 1990.

Mosshammer A.A., Non-being end evil in Gregory of Nyssa, VigCh 44 (1990) 136-167.

Oenler K., Aristotels in Byzanz, in: Antike Philosophie und byzantinisches Mitelalter: Aufsätze zur Geschichte des friechischen Denkens, München 1969, 272-286.

Orphanos M., Creation and Salvation according to St. Basil of Caesarea, Athens 1975.

Podskalsky G., Theologie und Philosophie in Byzanz, München 1977.

Podskasly G., Nikolaos von Methone und die Proklosrenaissance in Byzanz, OCP 42 (1976) 509-523.

Proclus et la Théologie Platonicienne, ed. A.Ph. Segonds - C. Steel, Leuven - Paris 2000.

Rich N.M., The Platonic Ideas as the Thoughts of God, "Mnemosyne" 7 (1954) 123-133.

Schultz D.J., Das Problem der Materie in Platons Timaios, Bonn 1966.

Sinnige T.G., Matter and Infinity in the Presocratic Schools and Plato, Assen 1968.

The Problem of Universals, ed. Ch. Landesman New York - London 1971.

Trizio M., Eleventh - to twelfth - century Byzantium, in: Interpretating Proclus: From Antiquity to the Renaissance, ed. S. Gersh, Cambridge 2014, 182-226. 